\title{
Correlation and Path Studies in Promising Bachelor's Button (Gomphrena globosa L.) Genotypes
}

\author{
Ashwini $^{1 *}$, A.R. Kurubar ${ }^{1}$, Shekhargouda Patil $^{1}$, Ashok Hugar ${ }^{1}$ and J.M. Nidagundi ${ }^{2}$ \\ ${ }^{1}$ Department of Horticulture, College of Agriculture, University of Agricultural Sciences, \\ Raichur - 584 104, India \\ ${ }^{2}$ Department of Genetics and Plant breeding, College of Agriculture, University of \\ Agricultural Sciences, Raichur - 584 104, India \\ *Corresponding author
}

\begin{tabular}{|l|}
\hline Ke y w or d s \\
AGS (Arabhavi \\
Gomphrena \\
Selection), \\
Correlation, Path \\
analysis, Genotype \\
and bachelors \\
button
\end{tabular}

\section{Introduction}

Bachelor's button (Gomphrena globosa L) is a tropical annual plant, commonly known as 'globeamaranth', 'everlasting', 'makhmali' and 'vadamalli' is an edible plant from the
The association and path analysis between nine different growth and flowering characters towards yield per plant were studied in ten bachelor's button (Gomphrena globosa L.) genotypes viz., AGS-1, AGS-5, AGS-6, AGS-7, AGS-8, AGS-9, AGS-10, AGS-13, AGS14 and AGS-15. The results indicated that that flower yield per plant had the positive and highly significant association with number of flowers per plant (0.772), test weight of 50 flowers (0.701), duration of flowering (0.626), number of primary branches per plant (0.583), number of secondary branches per plant $(0.555)$, flower diameter $(0.525)$ and length of stalk (0.483). The path coefficient analysis revealed that number of secondary branches had highest positive direct effect (0.6602) on flower yield per plant followed by, number of flowers per plant (0.5872), duration of flowering (0.5332), test weight of 50 flowers (0.4722), flower diameter (0.1200) and days to first flower bud initiation (0.0773), whereas, negative direct effect was executed by length of stalk $(-0.9452)$ followed by number of primary branches $(-0.3612)$ and days to 50 per cent flowering $(-0.0151)$. Number of primary branches had positive indirect effect on flower yield per plant through number of secondary branches (0.6535), Number of secondary branches via number of flowers per plant (0.4701), Length of stalk via number of secondary branches $(0.6515)$. Number of primary branches had negative indirect effect on flower yield per plant through length of stalk (-0.9251), Number of secondary branches via length of stalk $(-0.9015)$, Length of stalk via number of primary branches (-0.3535). Hence direct selection for number of secondary branches per plant, number of flowers per plant and duration of flowering is suggested for getting yield improvement. 
hairy as they are aged. The round-shaped or clover like or button like flower, blooms continuously throughout summer and early fall. It is native to Central America.

The flower yield is a complex character and is the result of interrelationship of various components. Therefore, information on direct and indirect effect of these components is of great importance. Study of such yield components may provide a solid ground for a successful varietal development programme. Correlation and path coefficient analysis furnishes information regarding the nature and magnitude of various associations and help in the measurement of direct influence of one variable on others. The correlation coefficient indicates the degree of relationship between characters. It is important to know the direct and indirect influences of yield component for selecting suitable genotypes for improving the yield. Therefore, present investigations were carried out to generate such information for bachelor's button.

\section{Materials and Methods}

The present experiment was conducted at Horticulture farm, Department of Horticulture, College of Agriculture, Raichur, during the year 2017-18, in Randomized Block Design (RBD) with three replications. To study the association between various characters towards the flower yield of ten genotypes of bachelor's button. Seedlings were transplanted at $60 \times 45 \mathrm{~cm}$ spacing in a flat beds.

All recommended practices were followed under irrigated condition. Correlation coefficient and path analysis were computed by the formula Weber and Moorthy (1952). Path analysis was carried out by using correlation coefficients to know the direct and indirect effects of the components on yield as suggested by Wright (1921) and illustrated by Dewey and Lu (1959).

\section{Results and Discussion}

The correlation coefficient among different characters showed that flower yield per plant had the positive and highly significant association with number of flowers per plant (0.772), test weight of 50 flowers (0.701), duration of flowering (0.626), number of primary branches per plant $(0.583)$, number of secondary branches per plant $(0.555)$, flower diameter (0.525) and length of stalk (0.483) (Table 1). Number of primary branches had significantly positive association with number of secondary branches (0.990), length of stalk (0.979), duration of flowering (0.967), number of flowers per plant (0.828), flower size (0.654), days to 50 per cent flowering (0.626), test weight of 50 flowers $(0.447)$ and days to first flower bud initiation (0.443). Significantly positive association of number of secondary branches with length of stalk (0.987), duration of flowering (0.967), number of flowers per plant $(0.800)$, days to 50 per cent flowering (0.674), flower diameter (0.633), test weight of 50 flowers $(0.433)$ and days to first flower bud initiation (0.417).

Length of stalk resulted in positive and significant association with duration of flowering (0.946), number of flowers per plant (0.753), days to 50 per cent flowering (0.702), flower diameter (0.598), test weight of 50 flowers (0.426) and days to first flower bud initiation (0.389). Flower bud initiation had shown positive and significant association with duration of flowering (0.422). It also found positive and non-significant with days to 50 per cent flowering (0.333), number of flowers per plant (0.286), flower diameter (0.227) and test weight of 50 flowers (0.052). Days to 50 per cent flowering showed significantly positive association with duration of flowering (0.519). It was found to be positive and non-significant with number of flowers per plant (0.336), flower diameter (0.215) and test weight of 50 flowers (0.082) (Table 2). 


\begin{tabular}{|c|c|c|c|c|c|c|c|c|c|c|c|}
\hline $\begin{array}{l}\text { SI } \\
\text { No. }\end{array}$ & Character & $\begin{array}{c}\begin{array}{c}\text { Number } \\
\text { of } \\
\text { primary } \\
\text { branches } \\
\text { per plant }\end{array} \\
\end{array}$ & $\begin{array}{c}\begin{array}{c}\text { Number } \\
\text { of }\end{array} \\
\text { secondary } \\
\text { branches } \\
\text { per plant }\end{array}$ & $\begin{array}{l}\text { Length } \\
\text { of stalk }\end{array}$ & $\begin{array}{c}\text { Days to } \\
\text { first } \\
\text { flower } \\
\text { bud } \\
\text { initiation }\end{array}$ & $\begin{array}{c}\text { Days to } \\
50 \% \\
\text { flowering }\end{array}$ & $\begin{array}{c}\text { Duration } \\
\text { of } \\
\text { flowering }\end{array}$ & $\begin{array}{c}\text { Flower } \\
\text { diameter }\end{array}$ & $\begin{array}{c}\text { Test } \\
\text { weight } \\
\text { of } 50 \\
\text { flowers }\end{array}$ & $\begin{array}{c}\text { Number } \\
\text { of } \\
\text { flowers } \\
\text { per } \\
\text { plant }\end{array}$ & $\begin{array}{c}\text { Yield } \\
\text { per } \\
\text { plant }\end{array}$ \\
\hline 1 & $\begin{array}{l}\text { Number of primary } \\
\text { branches per plant }\end{array}$ & 1.000 & $0.990^{* *}$ & $0.979 * *$ & $0.443 *$ & $0.626^{* *}$ & $0.967 * *$ & $0.654^{* *}$ & $0.447 *$ & $0.828^{* *}$ & $0.583 * *$ \\
\hline 2 & $\begin{array}{l}\text { Number of secondary } \\
\text { branches per plant }\end{array}$ & & 1.000 & $0.987 * *$ & $0.417 *$ & $0.674 * *$ & $0.967 * *$ & $0.633^{* *}$ & $0.433^{*}$ & $0.800^{* *}$ & $0.555^{* *}$ \\
\hline 3 & Length of stalk & & & 1.000 & $0.389 *$ & $0.702 * *$ & $0.946^{* *}$ & $0.598 * *$ & $0.426^{*}$ & $0.753 * *$ & $0.483 * *$ \\
\hline 4 & $\begin{array}{l}\text { Days to first flower bud } \\
\text { initiation }\end{array}$ & & & & 1.000 & 0.333 & $0.422 *$ & 0.227 & 0.052 & 0.286 & 0.230 \\
\hline 5 & Days to $50 \%$ flowering & & & & & 1.000 & $0.519^{* *}$ & 0.215 & 0.082 & 0.336 & 0.008 \\
\hline 6 & Duration of flowering & & & & & & 1.000 & $0.664 * *$ & $0.460^{*}$ & $0.790 * *$ & $0.626 * *$ \\
\hline 7 & Flower diameter & & & & & & & 1.000 & 0.185 & $0.654 * *$ & $0.525 * *$ \\
\hline 8 & Test weight of 50 flowers & & & & & & & & 1.000 & $0.469 * *$ & $0.701 * *$ \\
\hline 9 & $\begin{array}{l}\text { Number of flowers per } \\
\text { plant }\end{array}$ & & & & & & & & & 1.000 & $0.772 * *$ \\
\hline
\end{tabular}

*Significant at 5\% level: $0.361 ; * *$ Significant at $1 \%$ level: 0.462 
Table.2 Direct and indirect effects of component traits on flower yield of bachelors button genotypes

\begin{tabular}{|c|c|c|c|c|c|c|c|c|c|c|c|}
\hline $\begin{array}{l}\text { SI } \\
\text { No. }\end{array}$ & Character & $\begin{array}{l}\text { Number } \\
\text { of } \\
\text { primary } \\
\text { branches } \\
\text { per plant }\end{array}$ & $\begin{array}{c}\text { Number of } \\
\text { secondary } \\
\text { branches } \\
\text { per plant }\end{array}$ & $\begin{array}{l}\text { Length } \\
\text { of stalk }\end{array}$ & $\begin{array}{c}\text { Days to } \\
\text { first } \\
\text { flower } \\
\text { bud } \\
\text { initiation }\end{array}$ & $\begin{array}{c}\text { Days to } \\
50 \% \\
\text { flowering }\end{array}$ & $\begin{array}{c}\text { Duration } \\
\text { of } \\
\text { flowering }\end{array}$ & $\begin{array}{l}\text { Flower } \\
\text { diameter }\end{array}$ & $\begin{array}{c}\text { Test } \\
\text { weight } \\
\text { of } 50 \\
\text { flowers }\end{array}$ & $\begin{array}{c}\text { Number } \\
\text { of } \\
\text { flowers } \\
\text { per } \\
\text { plant }\end{array}$ & $\begin{array}{c}\text { Yield } \\
\text { per } \\
\text { plant }\end{array}$ \\
\hline 1 & $\begin{array}{l}\text { Number of primary } \\
\text { branches per plant }\end{array}$ & -0.3612 & 0.6535 & -0.9251 & 0.0342 & -0.0094 & 0.4150 & 0.0785 & 0.2111 & 0.4868 & 0.5834 \\
\hline 2 & $\begin{array}{l}\text { Number of secondary } \\
\text { branches per plant }\end{array}$ & -0.3576 & 0.6602 & -0.9015 & 0.0323 & -0.0102 & 0.3813 & 0.0759 & 0.2043 & 0.4701 & 0.5548 \\
\hline 3 & Length of stalk & -0.3535 & 0.6515 & -0.9452 & 0.0301 & -0.0106 & 0.3954 & 0.0718 & 0.2011 & 0.4426 & 0.4832 \\
\hline 4 & $\begin{array}{l}\text { Days to first flower bud } \\
\text { initiation }\end{array}$ & -0.1599 & 0.2755 & -0.4606 & 0.0773 & -0.0050 & 0.2835 & 0.0273 & 0.0244 & 0.1680 & 0.2305 \\
\hline 5 & Days to $50 \%$ flowering & -0.2261 & 0.4449 & -0.8322 & 0.0258 & -0.0151 & 0.3484 & 0.0258 & 0.0388 & 0.1974 & 0.0077 \\
\hline 6 & Duration of flowering & -0.3493 & 0.6381 & -0.9825 & 0.0326 & -0.0078 & $\mathbf{0 . 5 3 3 2}$ & 0.0797 & 0.2171 & 0.4645 & 0.6256 \\
\hline 7 & Flower diameter & -0.2363 & 0.4176 & -0.7088 & 0.0176 & -0.0032 & 0.4460 & 0.1200 & 0.0872 & 0.3846 & 0.5247 \\
\hline 8 & $\begin{array}{l}\text { Test weight of } 50 \\
\text { flowers }\end{array}$ & -0.1615 & 0.2856 & -0.5048 & 0.0040 & -0.0012 & 0.3088 & 0.0222 & 0.4722 & 0.2759 & 0.7012 \\
\hline 9 & $\begin{array}{l}\text { Number of flowers per } \\
\text { plant }\end{array}$ & -0.2992 & 0.5280 & -0.8925 & 0.0221 & -0.0051 & 0.5309 & 0.0785 & 0.2217 & 0.5877 & 0.7723 \\
\hline
\end{tabular}

(R): $0.362 ; \mathrm{R}^{2}(\%): 86.88$ 
Duration of flowering had significantly positive association with number of flowers per plant (0.790), flower diameter (0.664) and test weight of 50 flowers (0.460). Flower diameter had significantly positive association with number of flowers per plant (0.654) and it had positive non-significant association with test weight of 50 flowers (0.185). Test weight of 50 flowers had significantly positive association with number of flowers per plant (0.469). The correlation coefficient on flower yield per plant had positive and significant association with number of flowers per plant (0.772). This association of various characters contributing towards the improvement of yield either with positively or negatively established association among the respective characters indicates the basis for selection of the genotypes further improvement. The present findings are in close conformity with earlier findings by Usha et al., (2004), Miteva and Vasileva (2015), Shantappa et al., (2015) and Arulmani et al., (2016).

With the inclusion of more variables in correlation studies, the indirect association becomes more complex. Two characters may show correlation just because they are correlated with the third one. In such circumstances, path coefficient analysis provides an effective mean of finding out direct and indirect effects of association and permits a critical examination of specific forces acting to produce a given correlation and measure the relative importance of each factor. Among all the characters studied number of secondary branches had highest positive direct effect (0.6602) on flower yield per plant followed by, number of flowers per plant (0.5872), duration of flowering (0.5332), test weight of 50 flowers (0.4722), flower diameter (0.1200) and days to first flower bud initiation (0.0773), whereas, negative direct effect was executed by length of stalk (-0.9452) followed by number of primary branches (-0.3612) and days to 50 per cent flowering (-0.0151). Though the length of the stalk, number of primary branches per plant and days to 50 per cent, these three characters had direct negative effects their positive indirect influence on flower yield per plant was influenced through number of flowers per plant, duration of flowering, test weight of 50 flowers, flower diameter and days to first flower bud initiation. The number of primary branches per plant had indirect positive effects on flower yield per plant through number of secondary branches per plant, number of flowers per plant and duration of flowering. Days to 50 per cent flowering had indirect positive influence on flower yield per through duration of flowering, number of flowers per plant, test weight of 50 flowers and flower diameter. The characters such as number of secondary branches per plant, number of flowers per plant, duration of flowering, test weight of 50 flowers, flower diameter which had direct positive influence on the flower yield implies that the selections based on these characters will help in increased flower yield of the selection made. On the contrary the direct positive effect of length of stalk, number of primary branches per plant and days to 50 per cent flowering will not influence towards increasing the yield. However, their direct negative effect to some extent could be either neutralized or decreased through characters with indirect positive effect on fresh flower yield. The similar studies were in carried out to access correlation and path establishment among different yield attributing characters have also been reported by Kumar et al., (2012), Prakash et al., (2018) and Manjula and Nataraj (2016).

\section{References}

Arulmani, N., Chandrashekhar, S. Y., Ramesh, Y. S. and Rashmi, R., 2016, Correlation studies in gaillardia 
(Gaillardia pulchella Foug.) genotypes. Res. Environ. Life sci., 9(4): 458-460.

Dewey, J. R. and Lu, K. H., 1959, Correlation and path analysis of components of crested wheat grass seed production. Agron. J., 51: 515-518.

Kumar, M., Kumar, S., Singh, M. K., Malik, S. and Kumar, A., 2012, Studies on correlation and path analysis in chrysanthemum (Dendranthema grandiflora Tzvelev.). International $J$. Pl. Res., 25(2): 62-65.

Manjula, B. S. and Nataraj, S. K., 2016, Genetic correlation and path coefficient analysis in dahlia (Dahlia variabilis L.) genotypes under hill zone of Karnataka. The Bioscan, 11 (2):1089-1092.

Miteva, N. and Vasileva, S., 2015, Correlations between the vegetative and decorative indicators in china aster [Callistephus chinensis (L.) Nees] by type of cultivation. Scientific Papers, 59: 381-384.

Prakash, A., Mukesh, K., Chaman, S., Ankur, K., Dipankar, S. B. and Sopal, S., 2018,
Correlation and path analysis studies in chrysanthemum grandiflora (Dendranthema Pharmacognosy and Phytochemistry, 7(2): 3890-3893.

Shantappa, T., Katagi, Abhishek, Jagadeesha, R. C. and Halesh, G. K., 2015, Studies on genotypic evaluation and correlation studies in China aster [Callistephus chinensis (L.) Nees]. Indian Res. J. Genet. Biotech, 7(2): 179-186.

Usha, B. T., Jawaharlal, M., Kannan, M., Manivannan, N. and Raveendran, M., 2004, Correlation and path analysis in African marigold (Tagetus erecta L.). International Quart. J. Life Sci., 9(4): 1673-1676.

Weber, C. R. and Moorthy, H. R., 1952, Heritable and non-heritable relationship and variability of oil content and agronomic characters in the $\mathrm{F} 2$ generation of soybean crosses. Agron. J., 44: 202-209.

Wright, S., 1921, Correlation and causation. J. Agri. Res., 20: 557-585.

\section{How to cite this article:}

Ashwini, A.R. Kurubar, Shekhargouda Patil, Ashok Hugar and Nidagundi, J.M. 2019. Correlation and Path Studies in Promising Bachelor's Button (Gomphrena globosa L.) Genotypes. Int.J.Curr.Microbiol.App.Sci. 8(07): 721-726. doi: https://doi.org/10.20546/ijcmas.2019.807.087 